\title{
イメージセンサを用いた無人搬送車の高速走行 †
}

\author{
牧 野 俊 昭*・大 泉 純 一*・橋 本 直 人** $^{* *}$ \\ High-Speed Driving Control of an Automatic \\ Guided Vehicle Using an Image Sensor
}

Toshiaki MAKino*, Junichi OızUmi* and Naoto HaShimoto**

\begin{abstract}
High accuracy, high response guidance and high steering mechanism response at high speed are required to improve the travelling characteristics of an unmanned delivery cart (AGV: Automatic Guided Vehicle), which is a component of modern FA systems.

In this paper, an image sensor guidance scheme and steering mechanism for a high-speed AGV are developed considering limit velocity for stable travel and control system stability. Factors which effect on steering characteristics are examined through computer simulation and experiments. An Image sensor guidance scheme is considered by examining with an equivalent image sensor.

The sensor is attached to the steered and driven wheel, and detects a pre-set route by following guiding tape bonded to the floor.

In the experiment, the developed high-speed $\mathrm{AGV}$ is $100 \mathrm{~kg}$ load rated. The high-speed AGV was verified to travel smoothly on straight routes at $120 \mathrm{~m} / \mathrm{min}$, and on curved routes at $60 \mathrm{~m} / \mathrm{min}$ with as little as $\pm 5 \mathrm{~mm}$ amplitude and $1 \mathrm{sec}$. period hunting motion, which is less than the guiding tape width.
\end{abstract}

Key Words : automatic guided vehicle, high speed, hunting motion, image sensor guidance

\section{1. まえがき}

新しいFA システムを構築するとき，搬送経路を自由 に敷設し，柔軟に拡張や変更が行える無人搬送車(以下， $\mathrm{AGV}$ と称す) を中心とした無人搬送システムが必要不 可欠である ${ }^{1), 2)}$.

これらのシステムに関して, 少ない台数の AGVで, 決 められた搬送物を効率良く運ぶための運行制御方式や多 局間通信方式が多く提案されている(3) 6). また，狭くて， 複雑な搬送経路（分岐，合流，交差点など）の設置や長 距離搬送での安定した高速走行化に関する新しい誘導制 御方式，電動機制御方式なども提案されている7) 11). 従来の $\mathrm{AGV}$ では走行路上の媒体から走行情報を入力

$\dagger$ 第 25 回計測自動制御学会学術講演会 $(1986 \cdot 7)$ および第 1 回インテリジェント FA シンポジウム (1987·7) で発表

* (株) 日立製作所機械研究所 土浦市神立町 502

**（株）日立製作所笠戸工場 下松市東豊井 794

* Mechanical Engineering Research Laboratory, Hitachi, Ltd., Tsuchiura

** Kasado Works, Hitachi, Ltd., Kudamatsu (Received April 2, 1991)
して, 最大 $60 \mathrm{~m} / \mathrm{min}$ の速度で走行している.しかし, 媒 体の破損や走行速度を少し上げると左右の摇れ（以下， 蛇行と称す）が大きくなり，脱線走行することがある. これらの問題点を解決するため, AGV を含む移動体の 操舵性能を改善させる操舵制御方式の提案がなされてい る $^{12) \sim 17)}$.

本論文では，3 輪構成の $\mathrm{AGV}$ が直線路上を低蛇行で， 安定に高速走行することを目的に, 簡単な構造の走行操 舵機構，等倍型イメージセンサからなる視覚誘導装置な どを用いた操舵制御系の設計やシミュレーション計算に よる検討を行った ${ }^{18)}$. そして, 筆者らは開発した積載質量 $100 \mathrm{~kg}$ の $\mathrm{AGV}$ を走行路上 $120 \mathrm{~m} / \mathrm{min}$ の速度で直線走 行させたとき，蛇行の振幅が $5 \mathrm{~mm}$ （反射テープ幅 50 $\mathrm{mm}$ 以内）で小さく，かつ曲線走行路上に貼着した反射 テープに沿って旋回走行する場合では, $60 \mathrm{~m} / \mathrm{min} の$ 速 度で滑らかに追従走行することを確認したので，報告す る.

\section{2. 無人搬送車の高速走行化の開発目的}

筆者らは複雑な軌道敷設並びに拡張や変更の容易な複 


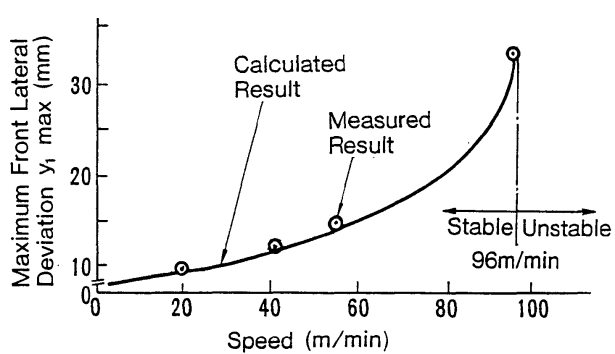

Fig. 1 Travelling characteristics of the conventional AGV

数台の AGV を中心にした F \& F (Flexible Control \& Free Layout) システム ${ }^{3)}$ を開発してきた。この中で，複 数台の $\mathrm{AGV}$ を効率良く運行するために, 最適な搬送要 求を $\mathrm{AGV}$ に割り付ける運行制御方式 ${ }^{4)}$ や運行指令を複 数台の AGV に無線で多局的に通信するスペクトル拡散 通信方式(5)開発してきた。このような構成で, 必要最小 限の AGV を用いてスループットの向上を図るには, AGV の高速走行化（たとえば従来の速度を 2 倍にする と, $120 \mathrm{~m} / \mathrm{min}$ で直線走行, $60 \mathrm{~m} / \mathrm{min}$ で旋回走行) が必 要不可欠になる. 従来の AGV では $60 \mathrm{~m} / \mathrm{min}$ 以上で直 線走行すると蛇行の振幅が大きくなり，脱線走行するこ とや曲線走行路では旋回走行の速度 $(30 \mathrm{~m} / \mathrm{min}$ 以下) を 落さなければ安定走行できないという問題点が指摘され ていた7゙.たとえば，文献 17)で検討した AGV が直線路 上を走行する場合では，Fig. 1 亿示す計算と実験の結果 から走行速度を上げていくと, 蛇行の振幅 $y_{1}$ が速度の 2 乗に比例して大きくなり，約 $100 \mathrm{~m} / \mathrm{min}$ 以上で脱線す る.この AGVでは, $96 \mathrm{~m} / \mathrm{min}$ 以下の速度において, 蛇 行の振幅 $y_{1}$ が大きくなっているが, 誘導走行している. しかし, 約 $100 \mathrm{~m} / \mathrm{min}$ 以上の速度では不安定な走行を行 う。この原因として種々考えられるが，シミュレーショ ン計算による操舵特性の結果からつぎのことがわかっ た。まず，検出系の検出精度 $(3 \mathrm{~mm} / \mathrm{bit})$ や検出遅れ(サ ンプリングタイム， $50 \mathrm{~ms}$ )による影響が大である。これ により，位相遅れなどが生じて操舵制御系が十分に追従 できず，蛇行の振幅が大きくなる.

そこで, AGV が高速走行しても，蛇行の振幅が小さ く, かつ滑らかに安定走行する操舵性能を得るために, 高速型無人搬送車(以下，高速 $\mathrm{AGV}$ と称す)を開発した。

\section{3. 高速型無人搬送車の概要}

\section{1 全体構成}

まず, 高速 AGV の構成と機能について述べる.前輪に 操舵機能と駆動機能を集約させた高速 AGV の構成を Fig. 2 に示す. 高速 AGV は車体を前側の一つの駆動·操

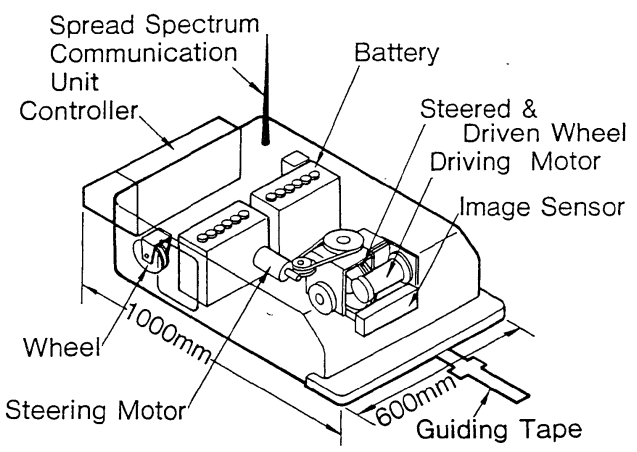

Fig. 2 Conceptual configuration of the Automatic Guided Vehicle (AGV)

舵輪（径 $180 \mathrm{~mm}$ ） と後側の二つの従動輪（径 $150 \mathrm{~mm}$ ) よりなる 3 輪構造のものである。車上のコントローラは 1 ボードマイコンからなり, 駆動回路を介して, DC の駆 動モー夕を速度制御すると共に, 走行路上の反射テープ の形状を駆動・操舵輪の前側に取り付けた視覚誘導装置 で検出し，車体状態量(たとえば，横方向の位置ずれ量， 姿勢角度など）を算出した後，反射テープに沿って走行 するように駆動・操舵輪を回動して高速 $\mathrm{AGV}$ を誘導走 行させる.

Fig. 2 に示す高速 $\mathrm{AGV}$ は長さ $1.0 \mathrm{~m}$, 幅 $0.6 \mathrm{~m}$, 高さ $0.35 \mathrm{~m}$ および質量 $120 \mathrm{~kg}$ (バッテリー含む)であり，100 $\mathrm{kg}$ の積載物を搭載することができる。この AGV は車上 のコントローラ, SS 無線通信装置などからなり, 地上計 算機からの運行指令を SS 無線通信装置で受信して, コ ントローラへ送り，コントローラからの走行指令により 駆動・操舵輪の速度制御を行って走行する.

高速 AGV の車体状態量を算出する視覚誘導装置の取 り付け位置と, 重心位置に対する駆動・操舵輪などの寸 法を Fig. 3 に示す.視覚誘導装置は車体の重心位置 G 対して前側に 1 個設けられ，走行路上の反射テープを $216 \mathrm{~mm}$ 幅の等倍型イメージセンサで検出した後, 進行

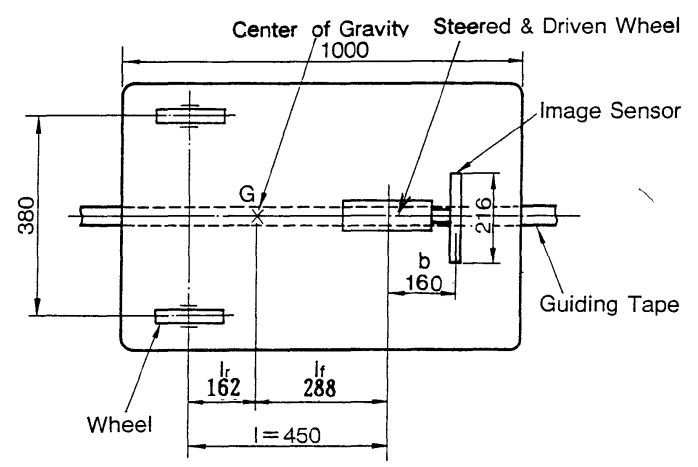

Fig. 3 Schematic layout of the AGV 


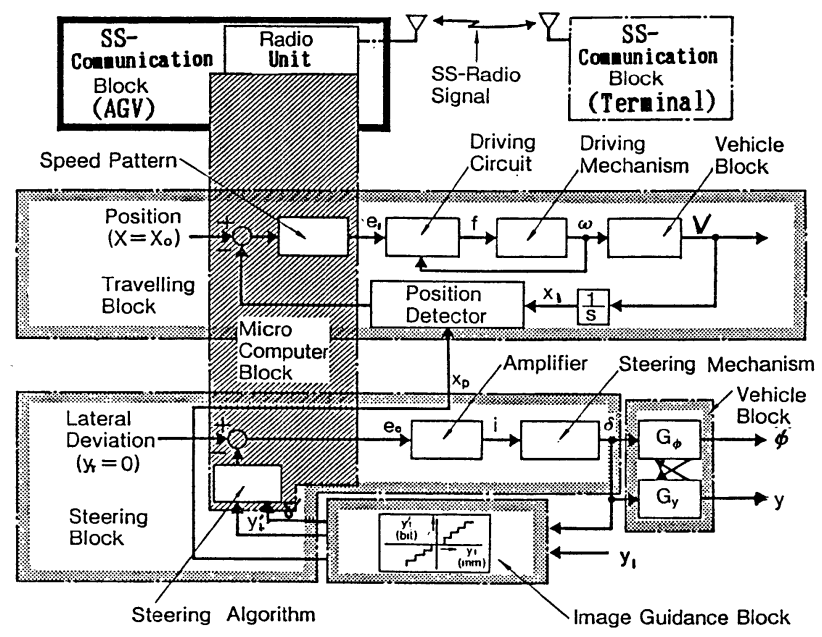

Fig. 4 Block diagram of the AGV

方向に対して直角方向のテープ中心とセンサ中心との位 置ずれ量（以下，軌道偏差量と称す） $y_{1}$ を出力するもの である。これにより, 高速 AGV の重心位置 Gでの軌道 偏差量 $y$ および姿勢角 $\phi$ は (1)式, (2) 式から求められ る $^{18)}$.

$$
\begin{aligned}
& y=y_{1}+\left(l_{f}+b\right) \cdot \psi \\
& \phi \fallingdotseq \frac{\dot{y}_{1}}{V}
\end{aligned}
$$

ここで， $l_{f}$ は重心位置と駆動・操舵輪間の寸法 (= $0.288 \mathrm{~m}), b$ は駆動・操舵輪の中心位置と等倍型イメー ジセンサの中心間の寸法 $(=0.16 \mathrm{~m}), V$ は走行速度であ る. 視覚誘導装置を含む高速 $\mathrm{AGV}$ の走行操舵制御系を Fig. 4 に示す。この制御系は主に, マイコン系, 走行系, 操舵系, 視覚誘導系などからなり, 操舵系の操舵信号 $e_{0}$ により台車系を制御するものである．走行系は目標位置 $x_{0}$ に対して, 走行パターンの速度信号 $e_{1}$ により, 加速, 定速, 減速などの速度制御を行った後, 視覚誘導系から の番地マーク信号により相対的にカウントして行き, 位 置信号 $x_{p}$ で停止位置決めする. また, 操舵系は目標の軌 道偏差量 $y_{r}$ (直進時, $y_{r}=0$, 施回・分岐時, $y_{r}=f(\delta)$ ) に対して, 視覚誘導系から出力された車体状態量（重心 位置での $y, \phi)$ に関する操舵量 $y_{s}$ にり, 操舵信号 $e_{0}\left(=y_{r}-y_{s}\right)$ を算出し, 後述する操舵機構系を介して駆 動・操舵輪の操舵角度 $\delta$ を制御することで車体全体を運 動させ, 操舵制御を行う。操舵量 $y_{s}$ は ( 3 ) 式で与えられ る.

$$
y_{s}=k_{1}^{\prime} y+k_{2}^{\prime} \dot{y}+k_{3}^{\prime} \delta
$$

ここで, $k_{1}^{\prime}, k_{2}^{\prime}, k_{3}^{\prime}$ は操舵ゲインである.

\section{2 視覚誘導方式}

今回，開発した等倍型イメージセンサ（以下，イメー

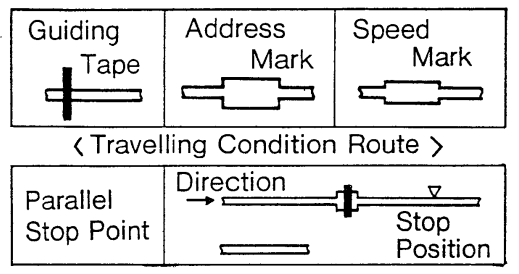

Fig. 5 Configuration of the guiding tapes on the layout

ジセンサと称す）による視覚誘導方式，回路構成などに ついて述べる.

本方式は Fig. 5 に示すように, 反射テープの污れ, 破 損が生じても信頼性の高い車体状態量を得るため, 直線 走行, 旋回走行, 分岐・合流走行, 交差点走行などの走 行条件を満足するような 3 種類の反射テープ形状を設定 した。たとえば, 番地信号マーク (幅 $150 \mathrm{~mm}$, 長さ 150 $\mathrm{mm}$ ）では反射テープ（幅 $50 \mathrm{~mm}$ ）の形状より幅広にな っており, イメージセンサで検出した後, 番地用の位置 信号 $x_{p}$ としてカウントする. 同様に, 速度マーク (幅 100 $\mathrm{mm}$, 長さ $150 \mathrm{~mm}$ ) では高速走行している高速 AGVの 速度を減速させる。

このような反射テープの形状を画像認識するイメージ センサではつぎのような問題点がある.

(1) AGVの上下振動によるピンボケや解像能力の 変動（焦点深度の変化による検出分解能の変動）

（2）走行速度によるセンサの読み取り遅れ（サンプ リングタイムの遅れ)

（3）走行路面の色と反射テープとの SN 比（コント ラスト）の低下

以上，述べたような諸問題を解決するため，イメージ センサの検討を行った. まず, 第 1 項に対してはレンズ 
光学系に必要な倍率, 焦点合せができるロッドレンズア レイを用い, 焦点深度を $25 \mathrm{~mm} \pm 10 \mathrm{~mm}$ と大きく取れ るようにした。第 2 項に対しては読み取りの走査周期を早 くして $1.58 \mathrm{~ms} /$ line とした。第 3 項に対しては反射テー プに照射して得られる反射光線の波長領域を考慮し, 567 $\mathrm{nm}$ の黄緑色の光を等倍型 LEDアレイと光学フィルタ を用い，得られた画像信号パターンをスムージングフィ ル夕 (パターンの規定值を決め, それ以下のパターンを 削除すること）により補正した。視覚誘導装置の構成, 仕様，外観などを Fig. 6, Photo. 1 に示す. 視覚誘導装 置は図示したように反射テープの形状から車体状態量 (たとえば， $y_{1}, x_{p}$ など) の変化を高精度 $(0.3 \mathrm{~mm} / \mathrm{bit})$ に, かつ高速 $(10 \mathrm{~ms})$ に検出する. その中心的役割を果 たすのが Photo. 1 に示したイメージセンサ（検出長 216 $\mathrm{mm}$ の 3640 画素, 16 本 $/ \mathrm{mm}$ ) である. それは走行路面 上から $25 \mathrm{~mm}$ 離して, 駆動・操舵輪の前側に取り付けら れている. LEDアレイからの光線を反射テープに照射 し，その反射光を 1 対 1 に並んだロッドレンズアレイに より $\mathrm{CCD}$ 基板上に結像させ, 映像信号を 2 值化信号に 変換して出力している. その検出特性の例を Fig. 7 に示 す.

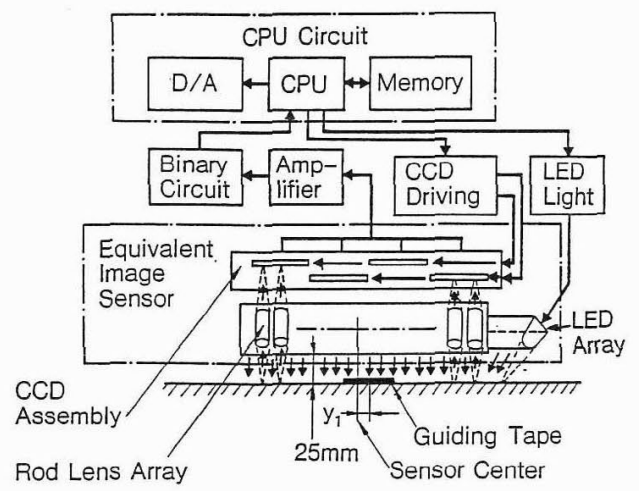

Fig. 6 Circuit configuration of the image guidance system
図示した特性は各種の反射テープ（ステンレス材，ア ルミニューム材など）を用いて，イメージセンサと走行 路面間の吵間（センサの取り付け高さ）を変化させたと きの二值化信号の值である。この結果から，ステンレス 材からなる反射テープを用いた場合， 5 〜 $35 \mathrm{~mm}$ の範囲 での隙間変化に対する 2 值化信号の変動值は 3 bit（約 $0.9 \mathrm{~mm}$ )であり，非常に小さいことが分かる。これによ り，ステンレス材からなる厚み $100 \mu \mathrm{m}$ の反射テープを 用いることにした。

\section{3 走行操舵機構}

高速 AGV の駆動・操舵輪を回動する走行操舵機構の 構成を Fig. 8 に示す。図示したように, 駆動・操舵輪(径 $180 \mathrm{~mm}$ ) の車軸を中心に, 駆動モー夕, 操舵モー夕, 位

Table 1 Specification of the image guidance system

\begin{tabular}{|c|c|}
\hline Item & Specification \\
\hline Sensor & $\begin{array}{l}\text { Equivalent CCD image sensor } \\
\text { Image scanning equivalent } \\
\text { Magnifying } 1: 1 \text { LED array }\end{array}$ \\
\hline Resolution & $0.3 \mathrm{~mm} / \mathrm{bit}(\mathrm{Gap} ; 25 \mathrm{~mm} \pm 10 \mathrm{~mm}$ ) \\
\hline Sampling time & $10 \mathrm{~ms}$ \\
\hline Detective length & $216 \mathrm{~mm}(3,640$ point $)$ \\
\hline Dimension & $250(1) \times 40(\mathrm{w}) \times 35(\mathrm{~h}) \mathrm{mm}$ \\
\hline Weight & $700 \mathrm{~g}$ \\
\hline $\mathrm{CPU}$ & 8 bit cpu, $32 \mathrm{~kb}$ memory \\
\hline
\end{tabular}

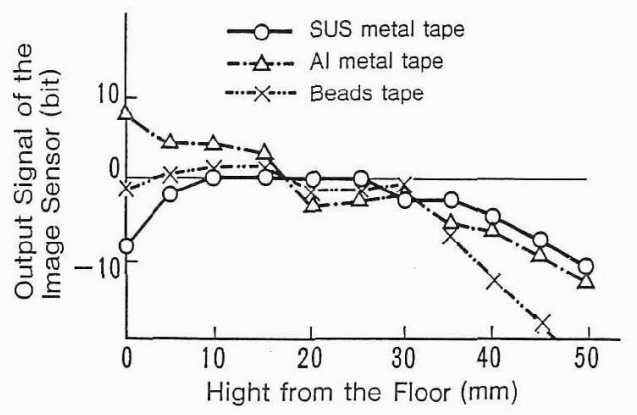

Fig. 7 Experimental characteristics of the image sensor

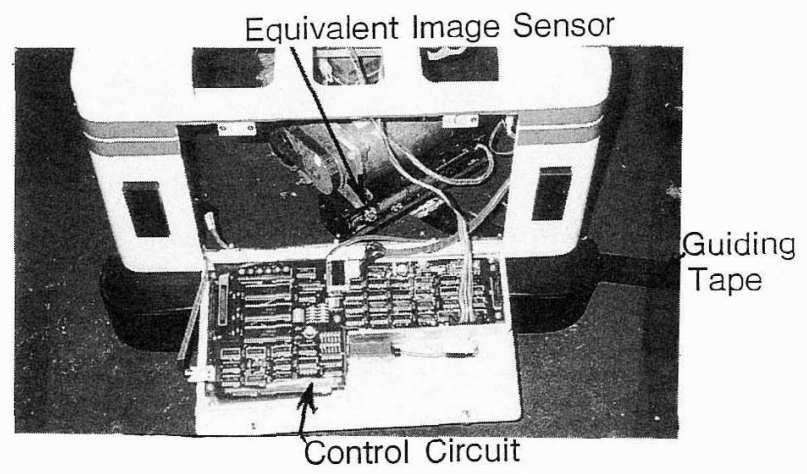

Photo. 1 Image guidance system 


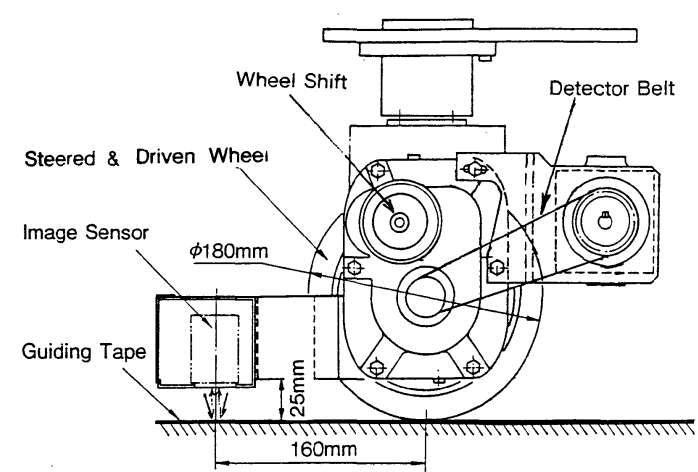

Fig. 8 Schematic layout of the driving and steering mechanism

置検出器, イメージセンサなどをバランス良く取り付け ている.ここで，イメージセンサは駆動・操舵輪の前側 $0.16 \mathrm{~m}$ の所に取り付けられ，走行路面に対して $25 \mathrm{~mm}$ の吵間を有している.

今回, 設計・製作した走行操舵機構は最大 $120 \mathrm{~m} / \mathrm{min}$ の走行速度が出る DC $24 \mathrm{~V}$ 駆動で $120 \mathrm{~W}$ の駆動モータ と, 左右 $90^{\circ}$ の操舵角度が得られる DC $24 \mathrm{~V}$ 駆動で 30 W の操舵モー夕から構成されている.この走行操舵性能 を把握するため, 高速 AGV を走行させて, 操舵モータの 電流 $i$ に対する操舵角度 $\delta$, 操舵角速度 $\dot{\delta}$ のステップ応 答特性を測定した。その波形を Fig. 9（a）に示す.

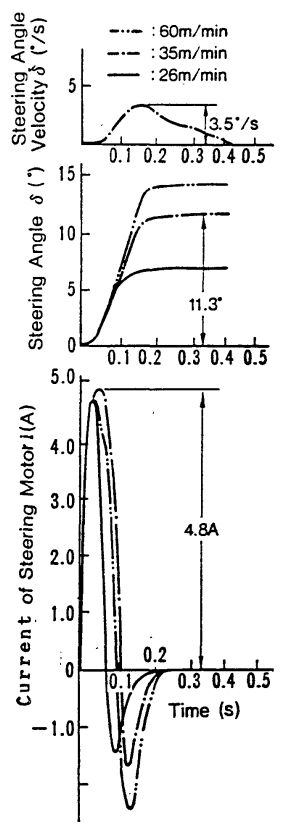

(a) Step response characteristics of the steering block
Fig. 9(a) に示した実験結果から, 操舵モー夕の電流 $i$ (4.8A で $0.05 \mathrm{~s}$ のインパルス) に対する操舵角速度 $\dot{\delta}$ (ピーク值 $\left.3.5^{\circ} / \mathrm{s}\right)$ の立上り特性は走行速度を変化させた 場合でも, 操舵角度 $\delta$ の立上り特性とほぼ同じ特性を示 すことが分かる。

ここで, 走行操舵機構の動特性として, (4) 式の 2 次 系を考慮することにした.

$$
\ddot{\delta}+2 \zeta \cdot \omega_{n} \dot{\delta}+\omega_{n}^{2} \delta=k_{1} \cdot e_{0}
$$

ただし, $\delta$ は操舵角度, $\omega_{n}$ は固有角振動数, $\zeta$ は減衰 係数比， $k_{1}$ は操舵機構系のゲインである.

Fig. 9(a)の実験結果と,（4)式を用いて計算したシ ミュレーション同定結果から, $\omega_{n}=57.1 \mathrm{rad} / \mathrm{s}(=9.1$ $\mathrm{Hz}), \zeta=0.7$ であった. これにより, 今回設計した走行操 舵機構は, 従来のもの $\left.{ }^{17}\right)\left(\omega_{n}=10.36 \mathrm{rad} / \mathrm{s}, \zeta=0.25\right)$ に比 べ，高応答で高減衰な特性になっている。

つぎに, 駆動・操舵輪の操舵角度 $\delta$ に対する高速 $\mathrm{AGV}$ の重心位置での姿勢角速度 $\dot{\phi}$ の実験結果と計算結果を Fig. 9( b ) に示す.

図示したように，ステップ入力 $11.3^{\circ}$ の操舵角度 $\delta に$ 対する姿勢角速度 $\dot{\psi}$ は, $11.8^{\circ} / \mathrm{s}$ であった.この結果から 実験値に対する計算值のパラメータを同定すると, 駆 動・操舵輪の $k_{f}, k_{r}$ は約 2,400 N/rad（=245 kgf/rad） であった.そこで,これらの值を用いて高速 $\mathrm{AGV}$ の安定 限界速度 $V_{c}$ を $(5)$ 式から求めてみると, $340 \mathrm{~m} / \mathrm{min}$ で

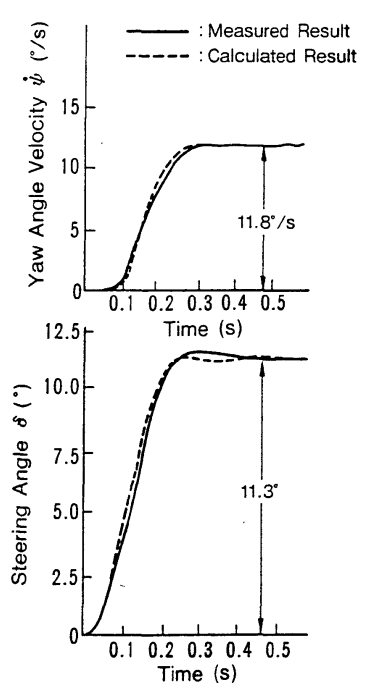

(b) Step response characteristics of the vehicle block

Fig. 9 Experimental steering characteristics of the developed AGV 
6001992 年 5 月

あった。

$$
V_{c}=\sqrt{\frac{k_{f} \cdot k_{r} \cdot g}{m\left(k_{f} \cdot l_{f}-k_{r} \cdot l_{r}\right)}} \cdot\left(l_{f}+l_{r}\right)
$$

\section{4. 高速走行化に関するシミュレーション検討}

高速 AGV の操舵制御系の主要諸元を Table 2 に示 す.これらの值は操舵制御系の設計 ${ }^{17)}$ に必要な值であ $\eta, k_{f}, k_{r}, \omega_{n}, \zeta, L$ などを実測から求めた。これらの值を 用いて, 高速 $\mathrm{AGV}$ が $120 \mathrm{~m} / \mathrm{min}$ の速度で安定走行す るための操舵制御系の安定性を検討する. 状態変数とし $\tau \boldsymbol{X}=[\delta, \dot{\delta}, y, \dot{y}, \phi, \dot{\phi}]^{T}$, 操作量として $\boldsymbol{U}=\left(k_{1}^{\prime} y+k_{2}^{\prime} \dot{y}\right.$ $\left.+k_{3}^{\prime} \delta\right)$ を用いると, 状態方程式は以下のようになる。

$$
\begin{aligned}
& \dot{\boldsymbol{X}}=\boldsymbol{A} \cdot \boldsymbol{X}+\boldsymbol{B} \cdot \boldsymbol{U} \\
& \boldsymbol{U}=-\boldsymbol{C} \cdot \boldsymbol{X}
\end{aligned}
$$

ただし，

$$
\boldsymbol{A}=\left[\begin{array}{ccccc}
0 & 1 & 0 & 0 & 0 \\
-\omega_{n}^{2}-2 \zeta \omega_{n} 0 & 0 & 0 \\
0 & 0 & 0 & 1 & 0 \\
\frac{k_{f}}{m} & 0 & 0-\frac{k_{f}+k_{r}}{m v} & \frac{k_{f}+k_{r}}{m} \\
0 & 0 & 0 & 0 & 0 \\
\frac{k_{f} l_{f}}{I} & 0 & 0 \frac{k_{r} l_{r}-k_{r} l_{r}}{I v}-\frac{k_{r} l_{r}-k_{f} l_{f}}{I}
\end{array}\right.
$$

$$
\left.\begin{array}{c}
0 \\
0 \\
0 \\
\frac{k_{r} l_{r}-k_{f} l_{f}}{m v} \\
1 \\
-\frac{k_{r} l_{r}^{2}-k_{f} l_{f}^{2}}{I v}
\end{array}\right] \quad \boldsymbol{B}=\left[\begin{array}{c}
0 \\
k_{1} \\
0 \\
0 \\
0 \\
0
\end{array}\right] \quad \boldsymbol{C}=\left[\begin{array}{c}
k_{3}^{\prime} \\
0 \\
k_{1}^{\prime} \\
k_{2}^{\prime} \\
0 \\
0
\end{array}\right]
$$

（7)式を(6)式に代入すると, 状態方程式は (8)式とな る.
第 28 巻 第 5 号

$$
\dot{\boldsymbol{X}}=(\boldsymbol{A}-\boldsymbol{B} \cdot \boldsymbol{C}) \boldsymbol{X}
$$

(8)式の状態方程式で表わされる系が漸近安定である ためには，すべての固有值の実部が負でなければならな い.よって, $\operatorname{det}(\boldsymbol{A}-\boldsymbol{B} \cdot \boldsymbol{C})=0$ から操舵ゲイン定数 $k_{1}^{\prime}, k_{2}^{\prime}$ (ただし， $k_{3}^{\prime}$ は 0.5 で一定とした場合) は Fig. 10 に示す 斜線範囲内であればよい. Fig. 10 の安定領域内で設定し た操舵ゲイン定数 $\left(k_{1}^{\prime}=0.02, k_{2}^{\prime}=1.0, k_{3}^{\prime}=0.5\right)$ を用い て，シミュレーション計算した一例を Fig. 11 (a )に示 す. 図中, (1)は操舵制御信号 (IN), (2) は前側の軌道偏差 量 $\left(y_{1}\right)$, (3)は操舵角度 $(\delta)$, (4)は重心位置での軌道偏差量 (y) である.この結果, 高速 AGV の初期の軌道偏差量 $y_{1}$ を $-50 \mathrm{~mm}$ にした場合, 操舵角度 $\delta$ と軌道偏差量 $y, y_{1}$ の運動は非同期になり，駆動・操舵輪を約 \pm 2.90 (3.3 $\mathrm{Hz}$ )で頻繁に制御し, 目標軌道に対して $y_{1}$ および $y$ がオ ーバーシュートするが, 高速 AGVは $3.0 \mathrm{~s}$ 後, 滑らかに 追従走行することが明らかになった。

高速 $\mathrm{AGV}$ の蛇行性能に及ぼす各種の操舵因子とし て, 視覚誘導装置の検出量子化要素, サンプリングタイ 厶, 取り付け位置 $(b)$, 駆動・操舵輪の取り付け位置 $\left(l_{f}\right)$ などが上げられる．前 2 者については先に報告したよう

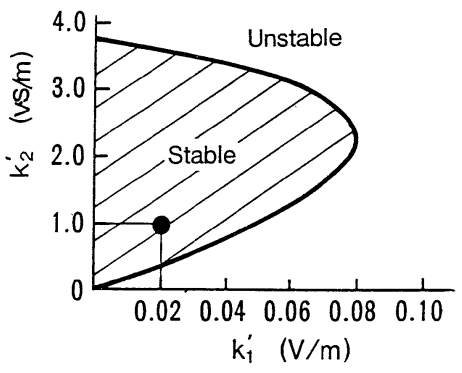

Fig. 10 Region of a local stability of the steering gain $(V=120 \mathrm{~m} / \mathrm{min})$

Table2 Developed AGV specification

\begin{tabular}{l|l}
\hline \hline \multicolumn{1}{c|}{ Item } & \multicolumn{1}{c}{ Specification } \\
\hline$m=120(\mathrm{~kg})$ & Self mass \\
$\left.I=5.6(\mathrm{kgm})^{2}\right)$ & Moment of inertia \\
$V=120(\mathrm{~m} / \mathrm{min})$ & Travelling maximum speed \\
$K_{f}=245(\mathrm{kgf} / \mathrm{rad})$ & Cornering coefficient of front wheel \\
$K_{r}=245(\mathrm{kgf} / \mathrm{rad})$ & Cornering coefficient of back wheel \\
$l_{f}=0.288(\mathrm{~m}), l_{f}=0.162(\mathrm{~m})$ & Length from wheel to center of gravity \\
$y(\mathrm{~m})$ & Lateral deviation of center of gravity \\
$\psi(\mathrm{rad})$ & Yaw angle \\
$\delta(\mathrm{rad})$ & Steering angle of steered and driven wheel \\
$k_{1}(\mathrm{rad} / \mathrm{V})$ & Steering amplifier gain \\
$e_{0}(\mathrm{~V})$ & Steering voltage \\
$f_{n}=9.1(\mathrm{~Hz}), \omega_{n}=2 \pi f_{n}$ & Frequency steering system \\
$\zeta=0.7$ & Damping factor of steering system \\
$L=0.01(\mathrm{~s})$ & Time delay on steering system \\
$k_{1}^{\prime}=0.02(\mathrm{~V} / \mathrm{m}), k_{2}{ }^{\prime}=1.0(\mathrm{v} \cdot \mathrm{s} / \mathrm{m})$ & Steering gain \\
$k_{3}^{\prime}=0.5(\mathrm{~V} / \mathrm{rad})$ & \\
\hline
\end{tabular}


に蛇行特性 ${ }^{17)}$ を改善する方法がわかっているので，後 2 者について今回検討した。その計算結果を Fig. 11(b)， (c)に示す.

Fig. 11(b)では, 駆動・操舵輪に取り付けるイメージ センサの位置 (寸法：b) を変えた場合における目標軌道 への収束特性を示す。 $b$ が $0.16 \mathrm{~m}$ 以上になると, $\mathrm{AGV}$ は安定走行する。しかし，イメージセンサを駆動・操舵 輪側へ近づけた場合（ $b$ が $0.08 \mathrm{~m}$ ) では，点線で示すよ うに発散特性となり，AGV は脱線する。また，AGV が 安定走行する場合でも, $b$ が $0.24 \mathrm{~m}$ の場合と, $b$ が 0.16 $\mathrm{m}$ の場合では前者のほうが後者に比して, 目標軌道への 追従性が悪くなる。

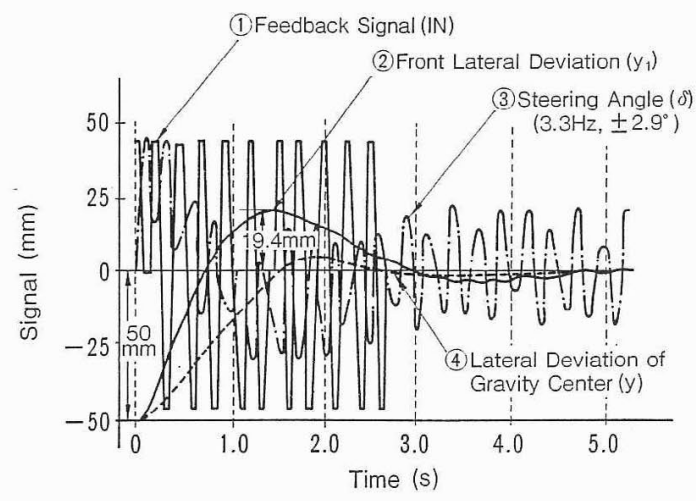

(a) Simulation result of the steering control

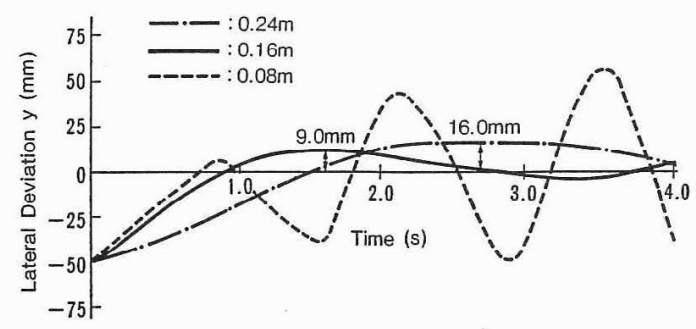

(b) Lateral deviation by length from image sensor to steered and driven wheel center ( $b$ )

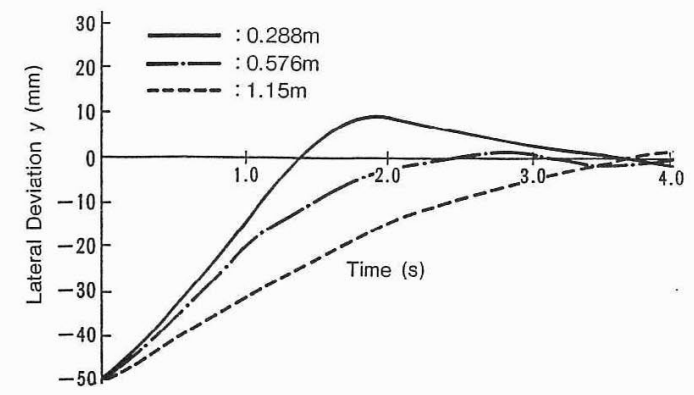

(c) Lateral deviation by length from steered and driven wheel to center of gravity $\left(l_{f}\right)$

Fig. 11 Simulation results of the developed AGV
Fig. 11(c)ではAGV の重心位置から駆動・操舵輪ま での寸法 $l_{f}$ を変えた場合における収束特性を示す。これ は AGVの走行操舵特性を変化させた場合の収束特性で あり，l が小さいほど目標軌道への追従性は良くなる が，オーバーシュートする。たとえば， $l_{f}$ が $0.576 \mathrm{~m} の$ 場合では一点鎖線で示すように, AGV は $2 \mathrm{~s}$ 後に目標軌 道へ収束する。しかし，Fig. 3 に示したように AGVの長 さ寸法が大きくなり，旋回走行するときの曲線走行路の 半径を大きくしなければならない。したがって，直線走 行での安定性と旋回走行での追従性を合せもつように， AGVの重心に対する駆動・操舵輪並びに視覚誘導装置 の取り付け位置 $\left(l_{f}, b\right)$ を考慮する必要がある。

\section{5. 高速 AGV の走行実験結果}

前項で検討した内容を盛り込んで開発した高速 $\mathrm{AGV}$ の外観をPhoto. 2 に示す。高速 AGV はSS 無線通信装 置を介して，地上のパソコンからの走行指令により 120 $\mathrm{m} / \mathrm{min}$ の最高速度で走行し, $3 \mathrm{~m} / \mathrm{min} \sigma$ 最低速度で停 止位置決めする。高速 $\mathrm{AGV}$ が走行操舵したときの蛇行 特性をFig. 12（ａ），（b)に示す。この場合，(1)走行速度 $V$ は促動輪に取り付けたタコジェネレータの出力值, (2) 台車前側の軌道偏差量 $y_{0}$ は高速 $\mathrm{AGV}$ の先端に取り付 けた視覚センサの出力值，(3)姿勢角速度 $\dot{中}$ は高速 $\mathrm{AGV}$ の重心位置に取り付けたジャイロの出力值, (4)操舵角度 $\delta$ は駆動・操舵輪の上部に取り付けたポテンショメータ の出力值などを測定した。

Fig. 12(a)では，高速 AGV が直線走行した場合の蛇 行特性を示し, $80 \mathrm{~m} / \mathrm{min}$ から $120 \mathrm{~m} / \mathrm{min}$ まで速度を 3 段階に変化させた場合, $y_{0}$ の最大振幅は土5 $\mathrm{mm}$ 以下て あった。高速 $\mathrm{AGV}$ の走行速度を上げていくと， $y_{0}$ の周 期は $1.5 \mathrm{~s}$ から $1.0 \mathrm{~s}$ まで変化（蛇行の周波数：0.66 $\rightarrow$

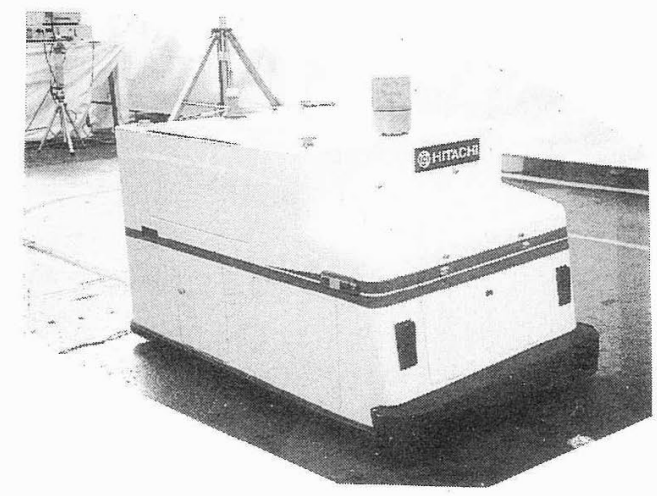

Photo. 2 Photograph of the developed AGV travelling on the floor with bonded guiding tape 


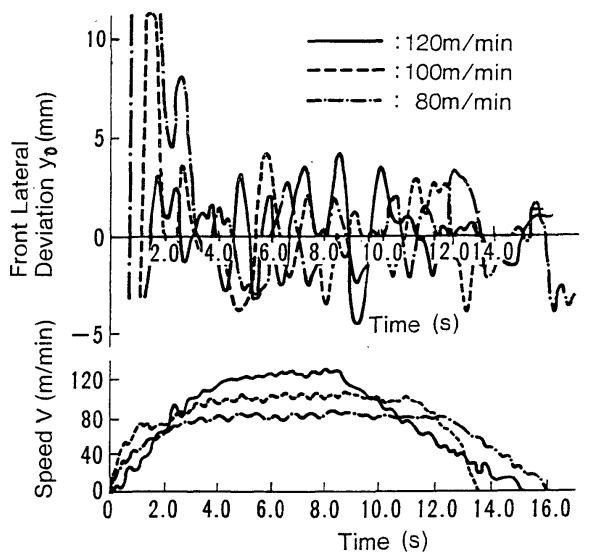

(a) Comparison of measured travelling speed

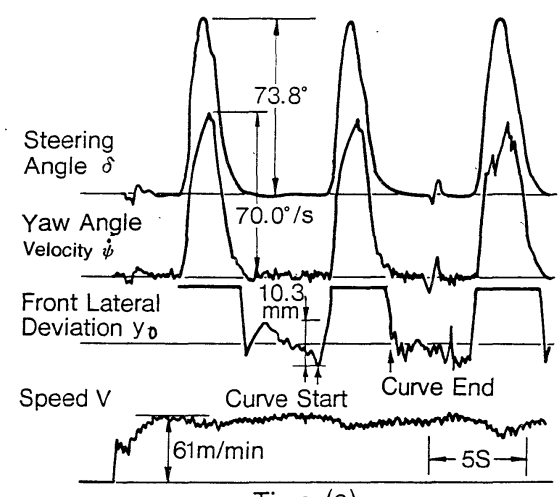

Time (s)

(b) Measured travelling characteristics on a curved route at $60 \mathrm{~m} / \mathrm{min}$

Fig. 12 Measured travelling characteristics of the developed AGV

$1.0 \mathrm{~Hz})$ する. また, $y_{0}$ の最大振幅も増え, $\pm 3 \mathrm{~mm}$ か ら土5 mm になるが, 安定に高速走行することを確認し た.

Fig. 12(b)では，高速 AGV が直線走行と旋回走行を 含むループ軌道 (直線走行路 $4 \mathrm{~m}$, 旋回半径 $0.45 \mathrm{~m}$ の曲 線走行路 $2 \mathrm{~m}$ ) 上を $60 \mathrm{~m} / \mathrm{min}$ の一定速度で走行した場 合を示す.この結果, 旋回走行時に $V$ が少し落ちるが, 曲線走行路に貼着した反射テープに沿って駆動・操舵輪 が追従して， $60 \mathrm{~m} / \mathrm{min}$ の速度で旋回走行することが可 能であることを確認した。

また, 旋回走行時の高速 AGVの姿勢角速度 $\dot{\phi}$ は $70 \%$ s であり, 大きくなっている.これは高速 $\mathrm{AGV}$ が旋 回走行するときの遠心力により, 駆動・操舵輪に加わる 力が増え, 横すべりがより大きく働くためであると考え られる. また, 駆動・操舵輪の角度 $\delta$ 変化に対して,

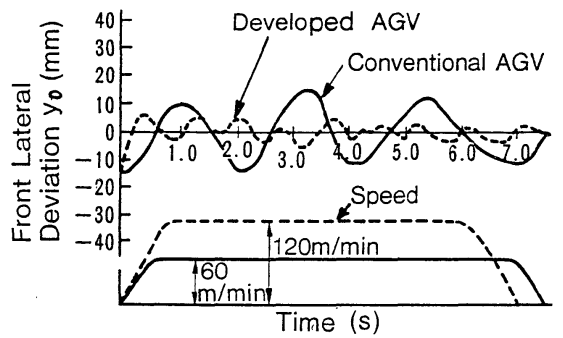

Fig. 13 Comparison of conventional AGV at $60 \mathrm{~m} / \mathrm{min}$ and developed AGV at $120 \mathrm{~m} / \mathrm{min}$

$\dot{\phi}$ が同位相で変化し良く追従していることが分かる。

以上，高速 $\mathrm{AGV}$ と従来 $\mathrm{AGV}$ による蛇行性能の比較 をまとめると, Fig. 13 に示すようになる，従来 $\mathrm{AGV}^{17)}$ では車体側に 16 個のホトセンサを取り付け,そのホトセ ンサの出力信号から操舵信号を求め, $50 \mathrm{~ms}$ のサンプリ ングタイムで出力していた。 その結果, 走行速度 $60 \mathrm{~m} /$ $\min$ 時, $\pm 15 \mathrm{~mm}$ の蛇行性能を有していたが，さらに高 速走行すると, 不安定走行し脱線する。これに対して, 高速 $\mathrm{AGV}$ では高精度な蛇行性能 $\left(y_{0}: \pm 5 \mathrm{~mm}\right)$ を有し, 安定でかつ高速走行 $(120 \mathrm{~m} / \mathrm{min}$ の直線走行と, $60 \mathrm{~m} /$ $\min$ の旋回走行）を実現できることを確認した.

\section{6. あとがき}

走行路上の反射テープを検出する 3 輪構成の無人搬送 車に関して, 簡単な構造からなる走行操舵機構と等倍型 イメージセンサからなる視覚誘導装置を用い, 蛇行を少 なくして高速走行する操舵制御系の設計やシミュレーシ ヨン計算による検討を行った。

これらの検討内容を取り入れた積載質量 $100 \mathrm{~kg}$ の高 速型無人搬送車を設計・製作して，120 m/min の直線走 行と, $60 \mathrm{~m} / \mathrm{min}$ の旋回走行を行った. その実験結果か ら, $1 \mathrm{~s}$ の周期でかつ蛇行の振幅が $\pm 5 \mathrm{~mm}$ 以下となり, 滑らかに走行していることを確認した。

\section{参 考 文 献}

1）高橋, ほか：無人搬送システムの利用実態とその分析, 無 人化技術，338-5，2/47（1988）

2) P.P. Bose: Basics of AGV Systems, American Machinist \& Automated Manufacturing, Speccial Report, 784, 106/122 (1986)

3）牧野, ほか：F \& F 自動倉庫制御システムの開発, 第 3 回 知能移動ロボットシンポジウム資料，105/110（1986）

4) 都島, ほか: 知識工学を応用した搬送車群の運行制御方 式，計測自動制御学会論文集，24-3，300/307（1988）

5）大泉，ほか：産業移動機械制御用スペクトル拡散通信装 置, 第 24 回 SICE 学術講演会予稿集, 347/348（1985）

6）津川，ほか：車両間通信による自律車両群の走行制御，計 測自動制御学会論文集， 26-9，76/83（1990）

7）米倉, ほか: 光学誘導形地上搬送ロボット「ホイバーサ」 の開発，日立評論，75-10，23/28（1975） 
8) P. Boegli : A Comparative Evaluation of AGV Navigation Techniques, Proceedings of the $3 \mathrm{rd}$ IC on AGVS, 169/180 (1985)

9）見浪，ほか：磁石補償式自律誘導方法, システムと制御, 31-5, 382/391 (1987)

10）隅元, ほか：単一インバータを用いた複数誘導電動機制御 の無人車走行への応用, 計測自動制御学会論文集, $23-5$, 505/511 (1987)

11）津村，ほか：無人搬送車とその制御，計測と制御， 26-7, 593/598 (1987)

12）畑 俊二：無人車の振舞いシミュレーション,神鋼電機技 報, 24-3，5/10 (1977)

13) S. Shadover, et al. : Steering Controller for Automated Guide Way Transit Vehicles, ASME Trans. Journal of Dynamic Systems Measurement \& Control, 100-3, 1/7 (1978)

14）小森, ほか：ランドマークを使った移動機械の制御，機械 技研所報, 37-1，1/10（1983）

15）川辺,ほか：車両操舵システムの動特性解析と四輪操舵機 構の設計，機論，56-530，70/74（1990）

16) C. N. Chang, et al. : Stability Analysis of Three and Four Wheel Vehicles, JSME International Journal, 33-4, 567/574 (1990)

17）牧野, ほか：無人搬送車の走行操舵特性の改善, システム 制御情報学会論文誌，4-3，103/110 (1991)

18）牧野,ほか：小形無人搬送車の誘導・通信, 第 1 回インテ リジェント FA シンポジウム資料，129/132（1987）

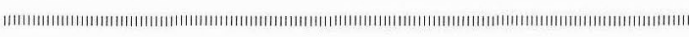

$$
\text { [著 者 紹 介] }
$$

牧 野 俊 昭 (正会員)

1971 年, 戸畑工業高校機械科卒業, 同年 (株) 日立製作所に入社. 1974 年同社茨城工 業高等専門学校卒業, 同年より 1 年間東京 大学工学部受託研究員. 現在同社機械研究 所研究員. FA システムのメカトロ制御の 研究抽よび自動倉庫, 無人般送車の製品開 発に従事. 日本機械学会などの正会員.

\section{大 泉 純 一 (正会員)}

1973 年, 静岡大学大学院電気工学専攻修 士課程修了. 同年(株) 日立製作所日立研究 所入社. 現在同社機械研究所主任研究員. 工業計器, 流体機械の制御, SS 通信の研究 などを行い，現在銀行端末装置の製品開発 に從事。電子情報通信学会の正会員.

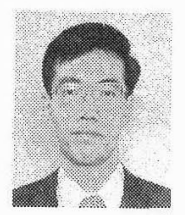

橋本直人

1978 年, 徳島大学大学院精密機械工学専 攻修士課程修了. 同年(株) 日立製作所笠戸 工場入社. 現在同工場主任技師。荷役運搬 機械 (クレーン), 自動倉庫, 無人搬送車, 物流システムなどの製品開発や設計に従 事.

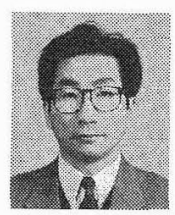

